Kamila Kamińska-Chełminiak

Katedra Książki i Historii Mediów

Wydział Dziennikarstwa, Informacji i Bibliologii

Uniwersytet Warszawski, Warszawa, Polska

ka.kaminska@uw.edu.pl

ORCID 0000-0002-6082-0444

http://doi.org/10.33077/zbkh.2018.12.kaminska

\title{
Cenzura PRL wobec Hańby domowej Jacka Trznadla (1989-1990)
}

\section{Abstract \\ The attitude of the Polish People's Republic censorship towards Hańba domowa by Jacek Trznadel (1989-1990)}

The aim of the article is to present the scale and nature of censor's interference in Hańba domowa by Jacek Trznadel and the reconstruction of the long way the author and his publisher were forced to go trying to publish the book without censor's crossings-out. The book was first published in 1986 by the Literary Institute in Paris (the Biblioteka Kultury series), and several months later by the underground publishing house called "NOWA". The book had become known even before it was published because of the interview, triggering very conflicting emotions, with Zbigniew Herbert conducted by Trznadel in 1985, which was then included in the publication. In Poland, the book was legally published for the first time right after closing down the Main Office for the Control of the Publications and Public Performances in June 1990. Before the collection of the interviews was legally published, the publisher - "Test" from Lublin - was forced to sue the Regional Office for the Control of the Publications and Public Performances in Lublin and the Main Office for the Control of the Publications and Public Performances in Warsaw, referring to the Supreme Administrative Court.

Key words: Censorship - Polish People's Republic - Office for the Control of the Publications and Public Performances - Case of Home shame - Jacek Trznadel - Supreme Administrative Court - communism.

Słowa kluczowe: Główny Urząd Kontroli Prasy, Publikacji i Widowisk - cenzura w PRL Jacek Trznadel - Hańba domowa - komunizm.

Celem artykułu jest przedstawienie skali oraz charakteru ingerencji cenzorskich w Hańbie domowej autorstwa Jacka Trznadla oraz rekonstrukcja 
zawiłej drogi, którą autor wraz z wydawcą pokonali, próbując wydać książkę bez skreśleń. Zbiór wywiadów ukazał się pierwotnie w 1986 r. w paryskim Instytucie Literackim (seria Biblioteki „Kultury”), zaś kilka miesięcy później w podziemnej Niezależnej Oficynie Wydawniczej NOWA ${ }^{1}$. O Hańbie domowej stało się głośno zanim jeszcze została wydana, ze względu na budzący skrajne emocje wywiad ze Zbigniewem Herbertem, przeprowadzony przez Trznadla w 1985 r., który następnie wszedł do tomu². W Polsce po raz pierwszy legalnie została wydana tuż po likwidacji Głównego Urzędu Kontroli Publikacji i Widowisk w czerwcu 1990 r. Zanim doszło do legalnego opublikowania książki, wydawca - spółka „Test” z Lublina-zdecydował się wejść na drogę sądową, zarówno z Okręgowym Urzędem Kontroli Publikacji i Widowisk (OUKPiW) w Lublinie, jak i Głównym Urzędem Kontroli Publikacji i Widowisk (GUKPiW) w Warszawie, zaskarżając wyrok do Naczelnego Sądu Administracyjnego.

Materiałem źródłowym artykułu są dokumenty GUKPPiW znajdujące się w AAN w Warszawie oraz materiały prasowe zgromadzone w Archiwum Związku Literatów Polskich.

Od momentu wydania pierwodruku w 1986 r. książka była wznawiana dziewięć razy, w tym sześć razy po 1989 r., co może świadczyć o zainteresowaniu, jakim cieszyła się przez lata ${ }^{3}$. Wydanie paryskie poprzedzono opublikowaniem wywiadu z Jerzym Andrzejewskim w „Kulturze” w związku ze śmiercią autora Popiołu i diamentu, która nastąpiła 20 IV 1983 r. ${ }^{4}$ Rozmowa zatytułowana Piekto zapomnienia i niebo pamięci została przeprowadzona

\footnotetext{
1 Nagrania dźwiękowe wywiadów przeprowadzonych przez Trznadla zostały zdeponowane przez pisarza w Magazynie Zbiorów Dźwiękowych i Audiowizualnych, natomiast rękopis w Magazynie Rękopisów BN.

2 Wypluć z siebie wszystko, „Kultura Niezależna” 1985, nr 14, s. 3-44. W jednym z wywiadów Trznadel wspominał o sugestiach, że Herbert mógł mieć zaniki świadomości: „Pamiętam, że Marian Brandys zapytał mnie, skąd wziął się impet tego wywiadu i czy przypadkiem Herbert nie był pod wpływem alkoholu. Otóż nie był", Zapamiętałem Herberta uśmiechniętego, wywiad z Jackiem Trznadlem, „Życie”, 12 VII 2001, s. 10.

3 Dotychczas ukazały się następujące wydania książki: wyd. Instytut Literacki, Paryż 1986; Niezależna Oficyna Wydawnicza, Warszawa 1986; Niezależna Oficyna Wydawnicza, Warszawa 1987; wyd. Instytut Literacki, Paryż 1988; wyd. „Test” Lublin 1990; wyd. Paweł Skokowski, Lublin 1993; Agencja Wydawnicza Morex, Warszawa 1994; wyd. „Świat Książki”, Warszawa 1996; Agencja Wydawnicza Morex, Warszawa 1997; Wydawnictwo „Antyk” - Marcin Dybowski, Warszawa-Komorów 2006. Pierwodruk zawiera wywiady z następującymi pisarzami: Zbigniewem Kubikowskim, J. Andrzejewskim, Wiktorem Woroszylskim, Witoldem Wirpszą, Jarosławem Markiem Rymkiewiczem, Julianem Stryjkowskim, Jackiem Bocheńskim, Z. Herbertem, Marianem Brandysem, Andrzejem Braunem, Janem Józefem Lipskim, Janem Józefem Szczepańskim. Rozmowa z Jackiem Łukasiewiczem, przeprowadzona 13 II 1981 r., została zamieszczona, po raz pierwszy, w wydaniu z 1990 r., natomiast rozmowa z Marią Janion - w wydaniu z 1996 r. Z kolei po odnalezieniu nieuszkodzonego nagrania rozmowy z Arturem Międzyrzeckim opublikowano ją w wydaniu z $2006 \mathrm{r}$.

4 Jacek Trznadel: rozmowa z Jerzym Andrzejewskim, „Kultura” 1983, nr 7-8, s. 18-35.
} 
we wrześniu 1981 r., a interlokutor Trznadla nie zdążył jej już autoryzować. Wstęp do książki został opublikowany na łamach „Kultury Niezależnej” w lutym $1986 \mathrm{r}^{5}$

Asumpt do przygotowania Hańby domowej dał Trznadlowi pamiętnik mówiony Aleksandra Wata, spisany przez Czesława Miłosza oraz opatrzony przezeń wstępem ${ }^{6}$. Zbiór wywiadów z pisarzami - jak mówił Trznadel - „,zanurzonymi w atmosferze socrealizmu" miał być nie tyle manifestem, ile świadectwem własnego uwikłania i błędów. Trznadel, który sam był w młodości zaangażowany ideologicznie, o czym pisze we wstępie oraz mówi w kolejnych wywiadach, chciał - jak thumaczył - ,rozliczyć się dla nauki przyszłych pokoleń” oraz wythumaczyć, jak wyglądała rzeczywistość 7 . „Jeśli tego nie uczynimy” - przekonywał - „to za parę lat będą znane tylko mity”.

Pisarz stawia tezę, że postawa moralna środowiska literackiego w Polsce lat 50. XX w. nosiła znamiona hańby domowej. Sami Polacy przyczynili się do tego, co w sferze zniewolenia duchowego zostało osiągnięte przez komunistów ${ }^{9}$. Dodaje jednak, że ,zasadnicze zniewolenie narodu polskiego nie udało się, jakkolwiek dokonywały się zniewolenia częściowe osób, grup społecznych" ${ }^{10}$. Założeniem Trznadla było odwołanie się do doświadczeń pisarzy aktywnych w latach 50 . XX w., bez wyznaczania ram problemom i wspomnieniom. Nie chodziło jedynie o odtworzenie ówczesnego stanu świadomości, ale także o jego ocenę z perspektywy lat. Trznadel odwołuje się również do swojej młodości, próbuje, jak pisze we wstępie, ,zbadać w jakimś sensie siebie z tamtych lat" ${ }^{11}$. Autor Hańby domowej, tak jak część jego rozmówców, był w OMTUR, ZMP, nosił czerwony krawat do zielonej koszuli, był członkiem PZPR a w pokoju miał portret Józefa Stalina. „Dlaczego ja też zaangażowałem się w stalinizm?" - pyta $^{12}$. I odpowiada, że pragnął zbawienia

\footnotetext{
J. Trznadel, Hańba domowa, „Kultura Niezależna” 1986, nr 17, s. 3-34.

6 Chciałem poprawić, z Jackiem Trznadlem rozmawia Magdalena Bajer, „Więź” 2004, nr 6,
} s. 88 .

Zob. również: Poezja jest sposobem istnienia, wywiad z Jackiem Trznadlem, „Tygodnik Solidarność" 1997, nr 42, s. 16-17; Krótka pamięć, z Jackiem Trznadlem rozmawia Barbara Sułek, „Tygodnik Solidarność" 1993, nr 32, s. 10; Z nami nie ma dyskusji, wywiad z Jackiem Trznadlem, „Ład” 1993, nr 28, s. 7-8; Skrajności historycznego losu, wywiad z Jackiem Trznadlem, „Kresy. Kwartalnik Literacki”" 1992, nr 12, s. 137-140; Uciec przed zawałem, z Jackiem Trznadlem rozmawia Jacek Wegner, „Rzeczpospolita”, 17 III 1991, s. 17; Rozważania o hańbie domowej, wywiad z Jackiem Trznadlem, „Wokanda” 1990, nr 2, s. 3-4.

8 Jacek Trznadel: rozmowy istotne, film dokumentalny, scenariusz M. Kozioł, M. Grabysa, rok prod. 2010. Film można obejrzeć na stronie internetowej Narodowego Instytutu Audiowizualnego, [online] http://ninateka.pl/film/jacek-trznadel-rozmowy-istotne [dostęp 26.04.2018].

9 J. Trznadel, Hańba domowa. Rozmowy z pisarzami, Lublin 1990, s. 9 i n.

10 Tamże, s. 9.

11 Tamże, s. 10.

12 Tamże, s. 13. 
świata, był młody i niedojrzały, a niedojrzałość potrafi „dawać te same wyniki, co mierność intelektualna czy po prostu głupota”"13. „O morderczych faktach stalinizmu nic właściwie nie wiedziałem" - pisze Trznadel, bowiem:

Nie istniała świadomość [...] że fakty są celowo ukrywane. [...] W zasięgu ręki i dalej prawdy - drukowanej nie było. Gdy usiłuję sobie przypomnieć, z jakim bagażem intelektualnym, wiedzą społeczną i historyczną wkraczałem na próg epoki stalinowskiej po wojnie, uderza mnie znikomość, wyrywkowość tego, co mogę sobie przypomniéćc ${ }^{14}$.

Tytuł książki wywołał mieszane uczucia wśród niektórych interlokutorów Trznadla. Jarosław Rymkiewicz był zadowolony, Andrzej Braun pogodził się z nim, natomiast Witold Wirpsza zażądał wycofania swojego wywiadu ${ }^{15}$. Trznadel, thumacząc genezę tytułu wspominał, że kiedy książka była już przygotowana do druku, nagle, gdzieś z pamięci wynurzyła się strofa z wiersza Cypriana Kamila Norwida pt. Duch Adama i skandal. Pomyślał wówczas: „Jeśli określenie było dobre w wieku XIX, dlaczego nie miałoby być dobre w wieku XX? Pochodząc z dawnej tradycji, umieszczało problem na trwałym planie moralnym"16.

\section{Kontrowersje wokół Hańby domowej}

Hańba domowa wywołała wiele dyskusji, polemik, głosów krytycznych i afirmatywnych. Główne zarzuty dotyczyły kategoryczności ocen zawartych w książce oraz bezwzględności w formułowaniu sądów ${ }^{17}$.

Marta Fik określiła Trznadla mianem ,antykomunistycznego Savonaroli”"18. Na łamach „Kultury Niezależnej” wyraziła pogląd, że choć intencje, które mu przyświecały były pozornie słuszne, to jednak książka powstała w gruncie rzeczy by ustalić, „kto jest czysty, brudny czy brudnawy” 19 .

13 Tamże, s. 14.

14 J. Trznadel, Hańba domowa. Rozmowy z pisarzami, Warszawa 2006, s. 12. Cytowanych fragmentów nie ma we wstępie z 1990 r. Trznadel uzupełnił go i dodał ponad jedną stronę maszynopisu.

15 Tamże.

16 J. Trznadel, Hańba domowa..., Warszawa 2006, s. 374.

17 Zob. M. Zaborowski, Między ocena a wyjaśnieniem, „Obecność. Niezależne Pismo Literackie" 1986, nr 16, s. 108-112; A. Kołek [T. Chrzanowski], Lot Trznadla nad skalanym gniazdem, „Miesięcznik Małopolski” 1987, nr 17, s. 1-15; J. Broeder, Czyściec niewinnych, „Tygodnik Mazowsze Solidarność” 1987, nr 204, s. 4 i n.; M. Jagiełło, Czarna dziura, „Krytyka” 1987, nr 25, s. 225-227; M. Lerski [R. Legutko], Stalinizm jako przygoda literacka, ,Arka” 1987, nr 18, s. 6-10; K.T. Toeplitz, Bagno, „Przegląd Tygodniowy” 1998, nr 47, s. 12; P. Śliwiński, To nie wymagało wielkiego charakteru, „Obecność. Niezależne Pismo Literackie” 1987, nr 20, s. 118-120; A. Werner, Król Edyp miał kaca, „Krytyka” 1987, nr 26, s. 193-197; K. Kersten, Hańba domowa - Potrzeba prawdy a tworzenie mitów, „Almanach Humanistyczny” 1989, nr 11, s. 80-85; W. Krajewski, Dlaczego nie wiedziałem o zbrodniach UB?, „Krytyka” 1989, nr 31, s. 81-86; M. Zaleski, Ułomni świadkowie, „Almanach Humanistyczny” 1989, nr 11, s. 86-88.

18 J. Trznadel, Hańba domowa..., Warszawa 2006, s. 376.

19 J. Lerska [M. Fik], Po co się spowiadać..., „Kultura Niezależna” 1987, nr 34, s. 96. 
Skonstatowała, że to, co zrobił Trznadel, ocierało się o pornografię. Sformułowała także opinię, że:

Nie wydaje się, ani pożytecznym, ani koniecznym wieczne roztrząsanie własnej nie dość chwalebnej przeszłości. Nie wydaje się celowym ani potrzebnym walenie się w piersi a tym bardziej podsuwanie twarzy do policzków. Nie wydaje się wreszcie ani sensownym, ani godnym zajęciem ustalanie rozmiaru win - szczególnie cudzych - i to wówczas, gdy onegdajsi winowajcy uwiarygodnili swą uczciwość dalszym życiem ${ }^{20}$.

Porównując Hańbę domowa do Onych Teresy Torańskiej, stwierdziła, że choć Trznadel miał solidniejsze przygotowanie merytoryczne i wydawał się lepszym rozmówcą niż młoda i reagująca nieraz zbyt emocjonalnie Torańska, to „W praktyce generalnie z nią przegrywa" ${ }^{21}$.

Wiktor Woroszylski, jeden z rozmówców Trznadla, dowiedziawszy się o tytule miał mu powiedzieć:

Kiedy godziłem się na wywiad, koncepcja Pańskiej książki była inna. Z czasem jednak najwidoczniej swoista koniunktura zniosła Pana zamierzenia w inną stronę. [...] Koniunktura na demaskowanie ludzi z opozycji jako niegdysiejszych stalinowców ${ }^{22}$.

Wobec książki zdystansował się również C. Miłosz ${ }^{23}$. Można było przewidzieć, że opublikowanie wywiadów z pisarzami, którzy, poza nielicznymi wyjątkami, byli zaangażowani politycznie w czasach największego terroru w Polsce i opatrzenie jej tytułem nawiązującym do hańby, wywoła liczne polemiki²4. Wydana w paryskiej „Kulturze” i w NOW-ej książka stała się wydarzeniem literackim i zdobyła Nagrodę Kulturalną „Solidarności” Komitetu Kultury Niezależnej.

Tom miał być w założeniu - jak pisał Trznadel - polemiką intelektualną z komunizmem, wyrażoną przez Miłosza w Zniewolonymi umyśle ${ }^{25}$. Trznadel stawia tezę, że w Polsce po wojnie dokonało się to, co za Norwidem nazywa hańbą domową. Na przełomie lat 40. i 50. XX w. literatura polska została zniewolona - przy udziale samych Polaków. Stawia swoim rozmówcom, ale również i sobie, pytanie: „Dlaczego postawy myślowe fałszywe i hańbiące, unicestwiające literaturę, stały się w pewnym momencie udziałem tak wielu ludzi z elity polskiej literatury?"26.

20 Tamże, s. 101.

21 Tamże, s. 103.

22 A. Bikont, J. Szczęsna, Lawina i kamienie. Pisarze wobec komunizmu, Warszawa 2006, S. 497 .

23 Wstawać rano, pisać a potem na jagody, wywiad z Czesławem Miłoszem przeprowadzony przez Adama Michnika, „Gazeta Wyborcza”, 8 VI 1991, s. 3.

24 Zob. również: J. Trznadel, Myślenie posttotalitarne, „Tygodnik Solidarność” 1991, nr 49, s. 16; tenże, Szkoła literackiego linczu, „Gazeta Polska” 2000, nr 32, s. 17.

25 J. Trznadel, Hańba domowa..., Warszawa 2006, s. 374.

26 Tenże, Hańba domowa..., Lublin 1990, s. 11. 
Hańba domowa to przyczynek do opisu szerszego zjawiska, które Miłosz nazywa „zniewoleniem umysłu” - to próba postawienia nie tyle diagnozy, ile refleksja nad jego korzeniami. W Zniewolonym umyśle Miłosz formułuje pytanie, którego istota przewija się przez karty książki Trznadla i myśli jego bohaterów: „dlaczego będąc daleki od ortodoksji, godziłem się na to, aby być częścią administracyjnej i propagandowej maszyny" ${ }^{27}$.

Hańba domowa to próba poznania stanu świadomości środowiska literackiego doby socrealizmu oraz motywów, dla których pisarze dali się uwieść - czy to ideologii, jak twierdzą niektórzy z nich, czy to, idąc za wywodem Herberta, Bolesławowi Bierutowi tout court. Istotę oraz przyczyny powstania tej książki tłumaczy, raczej przypadkowo, jeden z jej dramatis personae - A. Braun: „Dzisiaj ocena tego wszystkiego jest już dużo prostsza, chodzi jednak o to, żeby pokazać, w jaki sposób dochodziliśmy do tego, co jest dzisiaj [w 1985 r. - K.K.]”28. Wiele racji ma zatem Z. Herbert, który mówiąc o swoich kolegach po piórze, konstatuje: „Nie chodzi mi o żadne samokrytyki, ale zwykłą przyzwoitość i chłodną ocenę"29.

Książka Trznadla, a właściwie historie jego rozmówców, są próbą udzielenia odpowiedzi na pytanie, czy pisarze, o których mowa, to rzeczywiście ofiary - cytując Miłosza - heglowskiego ukąszenia, czy też - jak stwierdził Herbert - „targowisko próżności [...] wpisane w atmosferę Warszawki”, dla których motorem napędowym był luksus oraz bliskość władzy - jakiejkolwiek $^{30}$. Ponadto, zdaniem Trznadla, inaczej należałoby spojrzeć na akces do komunizmu uczyniony przez - jak pisze Trznadel - „stare konie” pokroju Jarosława Iwaszkiewicza lub Kazimierza Brandysa, a inaczej na ,pryszczatych", takich jak Woroszylski lub Braun. Trudniej bowiem zrozumieć postępowanie ludzi dorosłych, ukształtowanych ideowo i moralnie, od młodszego pokolenia, którego gorliwość w hołubieniu nowego systemu można tłumaczyć indoktrynacją oraz lukami w wykształceniu.

Motywy politycznego zaangażowania były różne. Adam Ważyk, który nie zgodził się na rozmowę, określił okres stalinizmu jako „nieinteresujący”. Diagnozując stan swojego ówczesnego umysłu stwierdził że, „oszalał, zwariował". Mniej oficjalnie, podczas spaceru w towarzystwie Trznadla jesienią 1981 r. wyraził opinię, że liberałów z okresu dwudziestolecia międzywojennego pchnęło w objęcia komunizmu to, że zachodnia demokracja nie potrafiła ocalić Europy od klęsk ${ }^{31}$. Trznadel napisał później we wstępie do swojej książki:

27 Cz. Miłosz, Zniewolony umyst, Paryż 1953, s. 11.

28 J. Trznadel, Hańba domowa ..., Lublin 1990, s. 268.

29 Tamże, s. 207.

30 Tamże, s. 194.

31 Tenże, Hańba domowa ..., Lublin 1990, s. 11. 
odmówił mi zdecydowanie. To była moja ostatnia z nim rozmowa [...] Ważyk powiedział: to jest nieinteresujące! - Potraktowałem to zrazu jako ironiczny wykręt i façon de dire. Potem zrozumiałem jednak, że odmawiał wszelkiego znaczenia okresowi, gdy był teoretykiem socrealizmu i budowanej w tym duchu tradycji. Uznał tamten czas za swoją przegraną i jednoznaczną klęskę literatury ${ }^{32}$.

Z kolei A. Braun próbując zrekonstruować, przy wydatnej pomocy rozmówcy, swój ówczesny sposób postrzegania świata i swojej twórczości, winą obarczył młodzieńczy wiek - był wtedy bardzo młody i bardzo gniewny. Tłumaczył Trznadlowi, że:

Jak dzisiaj patrzę na to, co wtedy pisałem ogarnia mnie zgroza, bo przestałem mówić we własnym imieniu. Przeszedłem na formę «my», zacząłem wypisywać bezosobowe slogany, jako poeta w ogóle się skończyłem, albowiem zaczęły to być plakatowe agitki. Wyrażały one raczej poglądy mojej partii niż moje, i to w coraz bardziej uproszczonej formie. Trochę mnie to niepokoiło ${ }^{33}$.

Dlaczego więc tworzył propagandową poezję - przypadek Wiosny sześciolat$k i$ - którą w 1985 r. nazwał ,użytkowymi robótkami”? "Mieliśmy rodziny” - twierdził - „z czegoś trzeba było żyć. Nie było tak jak dzisiaj, że pisarze systemu mają wille, samochody, i tak dalej. Myśmy nie byli skorumpowani w sensie materialnym, ale z czegoś trzeba było żyć" 34 .

Najostrzejsze oceny odnoszące się do „dość obrzydliwego okresu w dziejach literatury polskiej" formułuje Z. Herbert ${ }^{35}$. Już na początku wywiadu zaznacza, że rozmowa ma dotyczyć okresu, o którym nie lubi mówić i którego nie lubi wspominać oraz podkreśla: ,Jestem w dość trudnej sytuacji - nie byłem aktorem tego zniewolenia literatury"36. Herbert nie wierzy, w żadne ,heglowskie ukąszenie”. Twierdzi, że artystów podniecała nowa władza, np. zaproszenie do Belwederu, nagrody, rozmowy z Bierutem:

Surowy pan, ale sprawiedliwy, podziemie wytłukł, ale nas kocha. [...] Oczywiście, to targowisko próżności jest wpisane w atmosferę Warszawki, której nie lubię. To znaczy towarzyskie kontakty stoliczek w PIW-ie, stoliczek w Czytelniku, duże nakłady i podpisywanie książek, kwiatek w celofanie, wieczór autorski, pięć tysięcy opasłych i zmęczonych robotników przychodzi i bije brawo towarzyszowi pisarzowi. Pycha rosła. [...] Bo życie artystów było idyllą, podszytą co prawda strachem, że można zlecieć w ten okropny dół,

32 Tamże, s. 10.

33 Tamże, s. 263.

34 Tamże, s. 267.

35 Wywiad ze Z. Herbertem ukazał się również we francuskim czasopiśmie „L'Autre Europe” 1988, nr 17-18-19, s. 134-152. Rozmowa, o której mowa, została poprzedzona wstępem, z którym Trznadel nie w pełni się zgadzał. Zob. Polemika J. Trznadla z recenzją książki Hańba domowa autorstwa Agnieszki Grudzińskiej, ,Zeszyty Historyczne” 1989, nr 89, s. 236-237.

36 J. Trznadel, Hańba domowa..., Lublin 1990, s. 181. 
gdzie żyło realne społeczeństwo. Kluby, domy wypoczynkowe, wysoki standard, salon literacki pani Nałkowskiej, wyjazdy za granicę ${ }^{37}$.

\section{Problemy z cenzurą}

W 1989 r. wydawca złożył maszynopis w siedzibie OUKPiW w Lublinie. Cenzor zakwestionował 33 fragmenty książki, które jego zdaniem godziły w stosunki sojusznicze łączące Polskę i Związek Radziecki oraz zagrażały konstytucyjnemu porządkowi PRL ${ }^{38}$. Główne zarzuty, wymienione w raporcie miesięcznym z 29 IX 1989 r. sporządzonym na użytek wewnętrzny, oznaczonym jako „poufne”, można zawęzić do trzech obszarów:

- czynienia ,analogii między faszyzmem a ustrojem socjalistycznym, nazywanym obelżywie «czerwonym faszyzmem»";

- potraktowania stalinizmu jako prostej kontynuacji, a nie wypaczenia leninizmu;

- oskarżania ZSRR o dokonanie zbrodni na narodzie polskim ${ }^{39}$.

Cenzor, który dokonał kontroli prewencyjnej książki, zakwestionował obszerne fragmenty odnoszące się do zbrodni katyńskiej. Ten wątek był poruszany przez Trznadla w wywiadach m.in. z Herbertem, Woroszylskim, Lipskim i Wirpszą. Była również mowa o innych zbrodniach dokonanych przez Ludowy Komisariat Spraw Wewnętrznych (NKWD), zwłaszcza na Kresach Wschodnich, po zajęciu tych terenów przez Armię Czerwoną we wrześniu 1939 r. Cenzorzy, którzy realizowali politykę propagandową państwa w zakresie dostępu do informacji, kształtowaną na szczeblu poszczególnych wydziałów KC PZPR, byli niezwykle wyczuleni na punkcie informacji o zbrodniach radzieckich. Wszelkie wzmianki na ten temat, które mogły pojawić się w środkach masowego przekazu były traktowane jako ,godzące w sojusze PRL" i usuwane na etapie kontroli prewencyjnej. Poruszanie tematu radzieckich zbrodni na oficjalnym gruncie publicystycznym, literackim i naukowym stało się możliwe dopiero w 1990 r. W kwietniu tego roku, radziecka agencja TASS wydała komunikat, będący oficjalnym stanowiskiem rządu ZSRR na temat rzeczywistych okoliczności zbrodni katyńskiej, w którym - oprócz informacji o obozach NKWD - znalazło się również stwierdzenie, że tragedia katyńska była jedną z najcięższych zbrodni stalinizmu ${ }^{40}$.

\footnotetext{
37 Tamże, s. 194-195.

38 AAN, GUKPPiW, sygn. 2174, Informacje o bieżących ingerencjach za okres od 6 do 30 września 1989 (informacja bieżąca nr 125), s. 2.

39 Tamże.

40 W komunikacie napisano: „Na spotkaniach przedstawicieli kierownictwa polskiego i radzieckiego, w szerokich kręgach społeczeństwa od dłuższego czasu podnoszona jest kwestia wyjaśnienia okoliczności zagłady polskich oficerów, internowanych we wrześniu 1939 r. Historycy
} 
Jako podstawę prawną ingerencji w Hańbie domowej cenzor wskazał art. 2 pkt 2 i 3 ustawy o kontroli publikacji i widowisk z dnia 31 VII 1981 r., w myśl którego: „Korzystając z wolności słowa i druku w publikacjach i widowiskach nie można: [...] nawoływać do obalenia, lżyć, wyszydzać lub poniżać konstytucyjny ustrój Polskiej Rzeczypospolitej Ludowej” oraz „godzić w konstytucyjne zasady polityki zagranicznej Polskiej Rzeczypospolitej Ludowej i jej sojusze"41.

Wydawca książki odwołał się od decyzji OUKPiW w Lublinie do pierwszej instancji, czyli GUKPiW. Taką możliwość dawała mu wspomniana ustawa, która powstała z inicjatywy opozycji w 1981 r. Do tego czasu podstawę prawną działalności Głównego Urzędu Kontroli Prasy, Publikacji i Widowisk stanowił dekret o utworzeniu GUKPPiW (od 1981 r. GUKPiW) z 5 VII 1946 r., zredagowany dość ogólnikowo i liczący pół strony maszyno$\mathrm{pisu}^{42}$. Na podstawie rzeczonego dekretu utworzono cenzurę instytucjonalną, która miała charakter prewencyjny oraz, co rzadko podkreśla się w literaturze przedmiotu, represyjny ${ }^{43}$. Istnieją liczne dowody świadczące o tym, że wielotysięczne nakłady czasopism lub książek, posiadające zgodę GUKPPiW na druk, były wycofywane z obiegu kilka dni po wydaniu decyzji przez urząd kontroli, co narażało na ogromne straty właścicieli wydawnictw. Wystarczyło, że cenzor ponownie sprawdził ocenzurowany artykuł i dostrzegł w nim „niecenzuralne” zdanie, którego wcześniej nie zauważył, aby redakcja była zmuszona do wycofania z kolportażu całego nakładu. Bywały przypadki, że na etapie kontroli wtórnej, cenzor wykrywał „rażący błąd”, co skutkowało tym, że z księgarń wycofywano nakład a cenzora, który go popełnił, karano.

W sierpniu 1980 r. na mocy porozumienia Międzyzakładowego Komitetu Strajkowego w Gdańsku i Komisji Rządowej, wiceprezes Rady Ministrów Mieczysław Jagielski zobowiązał się, że rząd wniesie do Sejmu projekt

obydwu państw przeprowadzili szczegółowe badania tragedii katyńskiej, które obejmowały m.in. poszukiwanie dokumentów. W ostatnim czasie radzieccy archiwiści i historycy natrafili na pewne dokumenty o polskich żołnierzach, którzy przebywali w obozach NKWD ZSRR w Kozielsku, Starobielsku i Ostaszkowie. [...] Całokształt ujawnionych materiałów archiwalnych pozwala wyciągnąć wniosek o bezpośredniej odpowiedzialności Berii, Mierkułowa i ludzi im podległych za zbrodnię popełnioną w katyńskim lesie. Strona radziecka wyrażając głębokie ubolewanie w związku z tragedią katyńską, oświadcza, iż jest to jedna z najcięższych zbrodni stalinizmu”, Oświadczenie TASS, ,Rzeczpospolita”, 17 IV 1990, s. 9. Zob. również: K. Kersten, Prawda zwyciężyła, „Rzeczpospolita”, 17 IV 1990, s. 3; Oświadczenie rzecznika rzadu, „Rzeczpospolita”, 17 IV 1990, s. 9.

41 Dz.U. 1981,. nr 20, poz. 99.

42 Dz.U. 1946, nr 34, poz 210.

43 Zdaniem autorki artykułu należałoby wprowadzić nową kategorię określającą ten szczególny rodzaj represyjności, mianowicie represyjność konspiracyjną. W przeciwieństwie do modelu cenzury okresu dwudziestolecia międzywojennego, wycofywanie nakładów z kolportażu, księgarń i innych punktów dystrybucji odbywało się w tajemnicy i było bezprawne, czyli niepoprzedzone wyrokiem sądowym. 
ustawy, która określi kompetencje i zakres obowiązków organów kontroli44 . Prace nad ustawą zostały podjęte we wrześniu $1980 \mathrm{r}$. W negocjacjach nad jej treścią brali udział również przedstawiciele Episkopatu Polski. Ustawa weszła w życie 1 X 1981 r. Umożliwiała ona:

- Odwołanie się od decyzji OUKPiW do Urzędu Głównego (art. 13, pkt 3), który, w przypadku publikacji nieperiodycznych, był zobligowany podjąć decyzję w ciągu miesiąca.

- Zaskarżenie decyzji GUKPiW do Naczelnego Sądu Administracyjnego, na zasadach i w trybie określonym w Kodeksie postępowania administracyjnego (art. 15).

- Zaznaczenie w tekście (lub w odrębnej informacji albo w układzie wystawy) - na wyraźne żądanie autora - ingerencji organu kontroli publikacji i widowisk z podaniem jej podstawy prawnej (art. 14, pkt 1).

Dzięki ustawie ingerencje cenzury stały się jawne dla czytelnika, który widząc kwadratowy nawias z umieszczoną w nim podstawą prawną miał świadomość, że ten fragment książki został usunięty przez cenzora.

GUKPiW uchylił jedenaście spośród 33 ingerencji OUKPiW w Lublinie, dlatego też wydawca Hańby domowej zdecydował się zaskarżyć decyzję Urzędu Głównego do Naczelnego Sądu Administracyjnego (NSA) ${ }^{45}$. Decyzja sądu oraz dalszy bieg wydarzeń wskazują, że po wygranych przez opozycję wyborach, powszechne było uczucie, że losy cenzury są już przesądzone a jej decyzje stanowią problem nawet dla organów sądowniczych ${ }^{46}$.

Dnia 2 X 1989 r. odbyła się bowiem rozprawa przed NSA w Warszawie przeciwko Głównemu Urzędowi Kontroli Publikacji i Widowisk o zakaz rozpowszechniania fragmentów publikacji J. Trznadla ${ }^{47}$. Sąd wydał wyrok uchylający zaskarżoną decyzję GUKPiW, jednocześnie uznał, że nie jest w pełni kompetentny by określić, czy książka w ocenzurowanej wersji powinna się ukazać, gdyż „opinia Głównego Urzędu Kontroli Publikacji i Widowisk wydana została w sytuacji historycznie szczególnej”, dlatego też scedował podjęcie ostatecznej decyzji na Radę Ministrów. Sędzia wyraził opinię, że:

44 J. Skórzyński, M. Pernal, Kalendarium Solidarności 1980-1989, Warszawa 2005, s. 271.

45 Boje z cenzura, ,Gazeta Wyborcza”, 11 IX 1989, s. 1.

46 Oficjalna krytyka cenzury stała się możliwa po utworzeniu rządu T. Mazowieckiego. Nowy premier już w exposé wygłoszonym 24 VIII 1989 r. zapowiedział zniesienie urzędu kontroli. 10 I 1990 r. Seweryn Blumsztajn opublikował na pierwszej stronie „Gazety Wyborczej” artykuł pod znamiennym tytułem Po cholerę to to żyje, w którym wezwał do niezwłocznej likwidacji cenzury. Dzień wcześniej Barbara Labuda, posłanka Obywatelskiego Klubu Parlamentarnego, w sejmowej dyskusji nad budżetem GUKPiW stwierdziła: „Haniebna rola tego urzędu kończy się”. Likwidacja cenzury stała się kwestią czasu, zob. S. Blumsztajn, Po cholerę to to żyje, „Gazeta Wyborcza”, 10 I 1990, s. 1; Cenzura - nie! Kultura i RTV-tak, ,,Rzeczpospolita”, 10 I 1990, s. 1.

47 Składowi sędziowskiemu przewodniczył sędzia NSA Marian Flasiński. 
fakty historyczne są dość radykalnie krytykowane, a zasadność dawnych opinii jest dziś dyskusyjna. Dlatego rząd ustami swego rzecznika prasowego powinien zająć stanowisko, czy kwestionowane fragmenty książki godzą w sojusz miedzy PRL a ZSRR.

Wyrok był prawomocny i nie podlegał zaskarżeniu.

Decyzja NSA była bezprecedensowa, gdyż ustawa o Naczelnym Sądzie Administracyjnym z 31 I 1980 r. nie przewidywała możliwości scedowania decyzji na organ władzy wykonawczej. Ponadto, rzecznik rządu, którym była wówczas Małgorzata Niezabitowska, nie miał możliwości prawnych, by każdorazowo zajmować stanowisko w sprawie ingerencji GUKPiW oraz urzędów okręgowych ${ }^{48}$. Premier Tadeusz Mazowiecki zignorował uwagi cenzorów a książka ukazała się bez skreśleń.

\section{Wnioski}

Wobec licznych ingerencji cenzorskich w książce Hańba domowa J. Trznadla, wydawca zdecydował się skorzystać z możliwości odwołania od decyzji GUKPiW do NSA, którą dała mu ustawa z 31 VII 1981 r. o kontroli publikacji i widowisk. Cenzor z OUKPiW w Lublinie zakwestionował w tomie z wywiadami m.in. fragmenty wypowiedzi odnoszące się do radzieckich zbrodni z okresu wojny i po 1945 r. Choć znaczenie cenzury instytucjonalnej było w 1989 r. marginalne, ze względu na ogólnie znikomą liczbę ingerencji, to informacje dotyczące rzeczywistych sprawców zbrodni katyńskiej były konsekwentnie blokowane aż do końca istnienia PRL ${ }^{49}$.

Decyzja NSA była bezprecedensowa, gdyż sędzia jednocześnie uchylił postanowienie GUKPiW dotyczące utrzymania 22 skreśleń oraz nakazał Radzie Ministrów, by - ze względu na „szczególne historyczne okoliczności” towarzyszące transformacji - ustosunkowała się do decyzji GUKPiW. Decyzja sądu wskazywała, że po czerwcowych wyborach z 1989 r. powszechne było uczucie, że losy cenzury są już przesądzone, a jej decyzje nie znajdują społecznej akceptacji.

48 Supercenzor, czyli co Niezabitowskiej sąd chce zwalić na głowę, „Gazeta Wyborcza”, 2 X 1989, s. 2.

49 Ważną cezurą dla GUKPiW oraz OUKPiW była data 29 V 1989 r., kiedy Sejm znowelizował ustawę z 31 VII 1981 r. o kontroli publikacji i widowisk. Okres po wejściu jej w życie (6 VI 1989 r.) nie znajduje odpowiednika w dziejach cenzury PRL pod względem spadku liczby ingerencji. Najpoważniejsza zmiana dotyczyła art. 2 określającego kryteria ingerencji. Znowelizowana ustawa zwiększyła liczbę publikacji zwolnionych z kontroli wstępnej oraz zliberalizowała kryteria ingerencji. Rezultatem wejścia w życie ustawy był spadek liczby ingerencji o prawie 70\%, szerzej na ten temat zob. K. Kamińska, Koniec cenzury w PRL (1989-1990), ,Studia Medioznawcze" 2014, nr 3, s. 113-131. 


\section{Bibliografia}

Archiwalia:

Archiwum Akt Nowych, Główny Urząd Kontroli Prasy, Publikacji i Widowisk, Informacje o bieżących ingerencjach za okres od 6 do 30 września 1989 (informacja bieżąca nr 125), sygn. 2174.

Archiwum Związku Literatów Polskich, teczki z materiałami prasowymi poświęconymi cenzurze i Jackowi Trznadlowi.

Opracowania, artykuły w periodykach naukowych:

Bikont A., Szczęsna J., Lawina i kamienie. Pisarze wobec komunizmu, Warszawa 2006.

Kamińska K., Koniec cenzury w PRL (1989-1990), „Studia Medioznawcze” 2014, nr 3, s. $113-131$

Miłosz C., Zniewolony umyst, Paryż 1953.

Polemika J. Trznadla z recenzją książki Hańba domowa autorstwa Agnieszki Grudzińskiej, „Zeszyty Historyczne” 1989, nr 89, s. 236-237.

Skórzyński J., Pernal M., Kalendarium Solidarności 1980-1989, Warszawa 2005.

Trznadel J., Hańba domowa. Rozmowy z pisarzami, Lublin 1990.

Trznadel J., Hańba domowa. Rozmowy z pisarzami, Warszawa 2006.

Prasa:

Blumsztajn S., Po cholere to to żyje, „Gazeta Wyborcza”, 10 I 1990, s 1.

Boje z cenzura, „Gazeta Wyborcza”, 11 IX 1989, s. 1.

Broeder J., Czyściec niewinnych, „Tygodnik Mazowsze Solidarność” 1987, nr 204, s. 4.

Cenzura-nie! Kultura i RTV-tak, „Rzeczpospolita”, 10 I 1990, s. 1.

Chciałem poprawić, z Jackiem Trznadlem rozmawia Magdalena Bajer, „Więź” 2004, nr 6, s. 78-92.

Jacek Trznadel: rozmowa z Jerzym Andrzejewskim, „Kultura” 1983, nr 7-8, s. 18-35.

Jagiełło M., Czarna dziura, „Krytyka” 1987, nr 25, s. 225-227.

Kersten K., Hańba domowa - Potrzeba prawdy a tworzenie mitów, „Almanach Humanistyczny" 1989, nr 11, s. 80-85.

Kersten K., Prawda zwyciężyła, „Rzeczpospolita”, 17 IV 1990, s. 3.

Kołek A. [T. Chrzanowski], Lot Trznadla nad skalanym gniazdem, „Miesięcznik Małopolski" 1987, nr 17, s. 1-15.

Krajewski W., Dlaczego nie wiedziatem o zbrodniach UB?, „Krytyka” 1989, nr 31, s. 8186.

Krótka pamięć, z Jackiem Trznadlem rozmawia Barbara Sułek, „Tygodnik Solidarność” 1993, nr 32, s. 10

Lerska J. [M. Fik], Po co się spowiadać..., „Kultura Niezależna” 1987, nr 34, s. 96.

Lerski M. [R. Legutko], Stalinizm jako przygoda literacka, „Arka” 1987, nr 18, s. 6-10. Oświadczenie rzecznika rządu, „Rzeczpospolita”, 17 IV 1990, s. 9. 
Oświadczenie TASS, „Rzeczpospolita”, 17 IV 1990, s. 3.

Poezja jest sposobem istnienia, wywiad z Jackiem Trznadlem, „Tygodnik Solidarność” 1997, nr 42, s. 16-17.

Rozważania o hańbie domowej, wywiad z Jackiem Trznadlem, „Wokanda” 1990, nr 2, s. 3-4.

Skrajności historycznego losu, wywiad z Jackiem Trznadlem, „Kresy. Kwartalnik Literacki" 1992, nr 12, s. 137-140.

Supercenzor, czyli co Niezabitowskiej sąd chce zwalić na głowę, „Gazeta Wyborcza”, 2 X 1989, s. 2.

Śliwiński P., To nie wymagało wielkiego charakteru, „Obecność. Niezależne Pismo Literackie" 1987 , nr 20, s. 118-120.

Toeplitz K.T., Bagno, „Przegląd Tygodniowy” 1998, nr 47, s. 12.

Trznadel J., Hańba domowa, „Kultura Niezależna” 1986, nr 17, s. 3-34.

Trznadel J., Myślenie posttotalitarne, „Tygodnik Solidarność” 1991, nr 49, s. 16.

Trznadel J., Szkoła literackiego linczu, „Gazeta Polska” 2000, nr 32, s. 17.

Uciec przed zawatem, z Jackiem Trznadlem rozmawia Jacek Wegner, „Rzeczpospolita”, 17 III 1991, s. 17.

Werner A., Król Edyp miał kaca, „Krytyka” 1987, nr 26, s. 193-197.

Wstawać rano, pisać a potem na jagody, wywiad z Czesławem Miłoszem przeprowadzony przez Adama Michnika, „Gazeta Wyborcza”, 8 VI 1991, s. 3.

Wypluć z siebie wszystko, „Kultura Niezależna” 1985, nr 14, s. 3-44.

Z nami nie ma dyskusji, wywiad z Jackiem Trznadlem, „Ład” 1993, nr 28, s. 7-8.

Zaborowski M., Między ocena a wyjaśnieniem, „Obecność. Niezależne Pismo Literackie" 1986, nr 16, s. 108-112.

Zaleski M., Ułomni świadkowie, „Almanach Humanistyczny” 1989, nr 11, s. 86-88.

Zapamiętałem Herberta uśmiechniętego, wywiad z Jackiem Trznadlem, „Życie”, 12 VII 2001, s. 10.

Akty prawne:

Dz.U. 1981, nr 20, poz. 99.

Dz.U. 1946, nr 34, poz. 210.

Filmy:

Jacek Trznadel: rozmowy istotne, film dokumentalny, scenariusz M. Kozioł, M. Grabysa, rok prod. 2010. 